\title{
REGIONAL PATTERNING AMONG THE MEGALITHS OF GALICIA (NW SPAIN)
}

\begin{abstract}
Summary. Within the extensive plateau crossed by the upper Miño there are a vast number of tumuli. Their distribution is fairly homogeneous and they reach densities of up to 6 mounds per $\mathrm{km}^{2}$. The grave goods recovered from some of these monuments bear little relation to those in the coastal areas, especially so by the later part of the 3rd millenium BC. Recent surveys have found that some of the biggest concentrations of tombs are located near to natural passes or ridges that connect the inland plateau with the eastern districts of La Coruña and Pontevedra provinces. We suggest that proximity to crossing points between different areas was an important factor in the local setting of the mounds. On a larger scale the same principle might explain the occurrence of considerable clusters of monuments close to natural passes between regions that were especially important during this period.
\end{abstract}

\section{INTRODUCTION}

Galicia occupies the northern quadrant of the Iberian Peninsula. It is bounded by Portugal to the south and by the provinces of Asturias, León and Zamora to the east. To the north is the Cantabrian Sea, whilst the region is bounded by the Atlantic Ocean to the West. There are a series of mountain ranges in the east and in the south-east of Galicia, reaching heights of up to $2,000 \mathrm{~m}$ in some places; further to the west is a series of less important mountain ranges which extend from north to south. These are often described as the 'Galician Meridian Range'. Between these two areas the topography is less sharply defined. This inland area corresponds to the upper valley of the River Miño which attains an average height of 500-600 m (Figure 4). Closer to the coast, the mountain ranges were greatly affected by erosion and also by tectonic events. The coastline is sharply indented, particularly along the Atlantic where there are a number of deep inlets or rias. The whole region has an oceanic climate, although this is more continental and less humid farther inland (Nonn 1966; Pérez Alberti 1986).

The megaliths in Galicia can be linked with those in Portugal to the north of the river Douro. Together they constituted a well defined 'North-Western province' within the Iberian Peninsula. We have recently synthesised this evidence, combining the results of our own research with those of other workers (Criado and Fábregas 1989). This enabled us to characterise some of the distinctive features 
of the megalithic tradition in this region; we considered the distribution and density of the tumuli and megalithic constructions, along with their phasing and chronology. We also offered a social interpretation of the archaeological sequence, emphasizing the different strategies suggested by ritual activity at these sites. We must begin by summarising the main findings of that research.

In contrast to other areas, the mounds and their internal structures are small, while corbelled chambers and multi-period constructions are absent. On the other hand, the density of these monuments is among the highest in Europe: for example, in the province of Ourense early studies recorded sixty tumuli over an area of only $90 \mathrm{~km}^{2}$ (López Cuevillas 1959). More recent work shows that there are 800 tumuli in other study areas which cover a total extent of only $1200 \mathrm{~km}^{2}$ (Criado 1988 and 1989). In the north of Portugal, in the Serra da Aboboreira, fifty tumuli have been discovered in little more than $25 \mathrm{~km}^{2}$ (Jorge 1988).

Their general distribution extends across every kind of landscape, from the shoreline to the mountain ranges of the interior. However, their density is by no means even and recent investigations reveal a contrast between the concentration of monuments on the relatively high ground of the interior and a lower density of sites in the lowlands towards the coast (Criado 1989b). This probably reflects the traditional contrast between valleys and mountains, visible in modern land-use. This is partly explained by the physical characteristics of these environments (for example their local climate), and partly by the different requirements of settlement in each of these areas. We will examine these issues in Section 3 of this paper.

At a detailed level several factors affect the siting of these monuments. They include the availability of suitable raw materials and the presence of enough workers to build them.

Above all, symbolic or ritual considerations must have determined the precise location of the monuments. They have certain novel features, for they are the first sites in Galician prehistory to stand out in the landscape and they seem to have been designed to last for a considerable period of time. Tumuli appear in isolation and in small groups, but there are also extensive cemeteries that include more than twenty monuments and may have developed over more than a thousand years (Jorge 1989). These concentrations are a characteristic feature of north-west Iberia. We shall put forward a possible interpretation of this phenomenon.

The development of Galician megaliths has been divided into three phases. The earliest is characterised by single chambers; these are succeeded by passage-graves and then by cists and/or other paramegalithic structures (Fábregas 1989; Rodríguez Casal 1990). There are very few radiocarbon dates (Fábregas 1988), but these from the north of Portugal are consistent with this scheme: the simple dolmens can date from the start of the fourth millenium $\mathrm{BC}$, and passage tombs seem to be found from the third millenium. Otherwise we have little to guide us. There are no dates for the supposedly 'late' tumuli and here the chronology still depends on artefact associations. At the same time, mounds with simple chambers may span two millenia. Finally, there are no dates for undeveloped passage tombs and here the chronology is based on comparisons with monuments in Castille and the Portuguese Beira.

Many of these problems arise from the traditional perception of megaliths as a unitary 'cultural' phenomenon, with an almost biological sequence of appearance, development and extinction. More recent research has adopted a contextual approach and has

OXFORD JOURNAL OF ARCHAEOLOGY 
considered the megalithic mounds in relation to changes in the visibility of the monuments and their various attributes, including grave goods. This work goes beyond chronological studies to investigate the meanings of these monuments within the societies that built them (Criado and Fábregas 1989; see also Criado 1989a).

As a result of this work, we can consider a number of new questions and approaches. In particular, we have recently suggested the existence of regional patterning in the development of Galician megaliths (Fábregas 1990 and 1991). We have also defined some of the social and symbolic factors that may have determined the location of the tumuli (Criado 1989a and $1989 \mathrm{c})$. Taking these approaches together, we can construct a hypothetical model to explain the existence of large concentrations of tumuli in Galicia. This takes us beyond the study of megaliths in their own right and offers an opportunity to consider the role of mobility and communication between different areas and even different social groups. Section 2 of this paper considers the evidence for regional patterning among these monuments; Section 3 analyses their location; Section 4 is concerned with the siting of the large cemeteries; and, finally, Section 5 considers the importance of mobility.

\section{REGIONAL PATTERNING: THE CASE OF THE INNER PLATEAU}

Some years ago (Fábregas 1988a: 68-69), we suggested that the architectural variants amongst the megaliths of north-west Iberia were not only the result of chronological change, as had been generally assumed, but also a product of social and economic factors that differed from one area to another. Detailed analysis of the lithic artefacts found in the tumuli revealed the existence of regional patterning and also gave more specific dating evidence for these sites, particularly those belonging to the later part of the sequence (Fábregas 1991). This allowed us to identify an inland area, focusing on the upper Miño and extending into the higher ground to the north and west. This region could be defined by a concentration of artefacts made from polished stone: maceheads, chisels, double axes, hoe blades and double adzes, all of which were originally found in tumuli (Figures 1 and 7).

It is unwise to define this 'tradition' exactly, since it must have formed only one component of contemporary material culture; these artefacts come from funerary deposits, nearly all of which were explored under unsatisfactory conditions. However, there is some reason to suppose that these artefact types all belong to the same period; in particular, there are a number of associations between them, especially the maceheads, hoe blades and chisels. Unfortunately, few of these finds are well documented, especially the discoveries of double axes. Nevertheless, the best recorded of the tombs seem to have been used only occasionally, and perhaps only once. This lends support to the idea that the artefacts found in these sites were contemporary with one another.

There are no radiocarbon dates, but a number of features suggest that this material belongs to a developed stage in the sequence. There is a general relationship between the maceheads, double axes and double adzes and their counterparts in Western Europe (Fábregas 1988b: 41-49). Their dates canot be very different, and on the basis of French or English examples, they would probably belong to the last centuries of the third millenium BC (Le Roux 1979: 55; Gachina et al. 1975: 369; Bocquet and Houot 1982: 90-91; Delibrias and Le Roux 1975: 79 and 81; Roe 1979: 38; Smith 1979: 15). Moreover, in Galicia, this material is generally associated

OXFORD JOURNAL OF ARCHAEOLOGY 

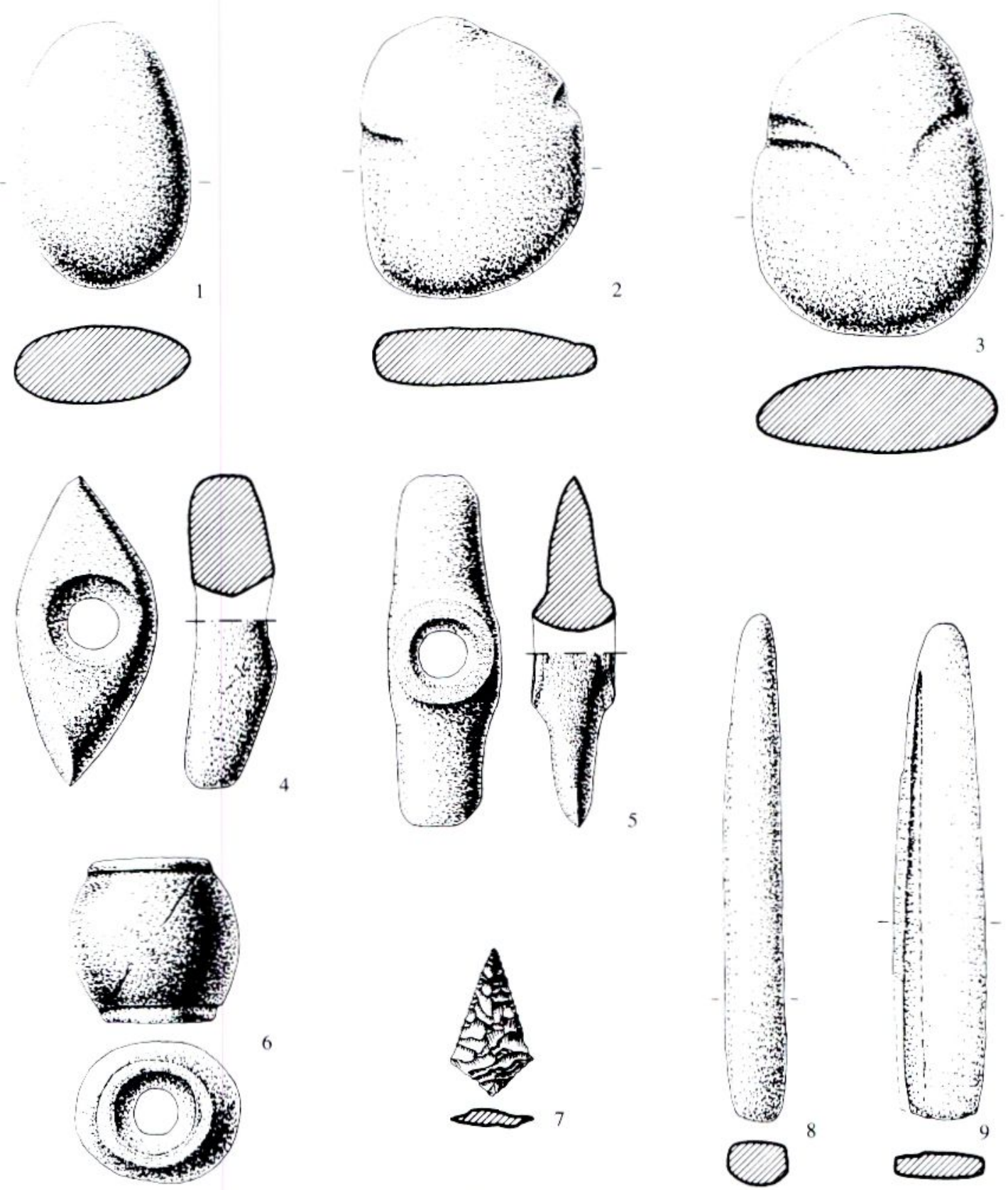

Figure 1

Some of the artifact types used to define contrast between the inland and coastal areas: 1. Pebble-idol; $2,3$. Argalo type idols; 4. Double axe; 5. Double adze; 6. Mace head; 7. Arrowhead; 8. Ground-stone chisel; 9. Ground-stone hoe blade.

OXFORD JOURNAL OF ARCHAEOLOGY 


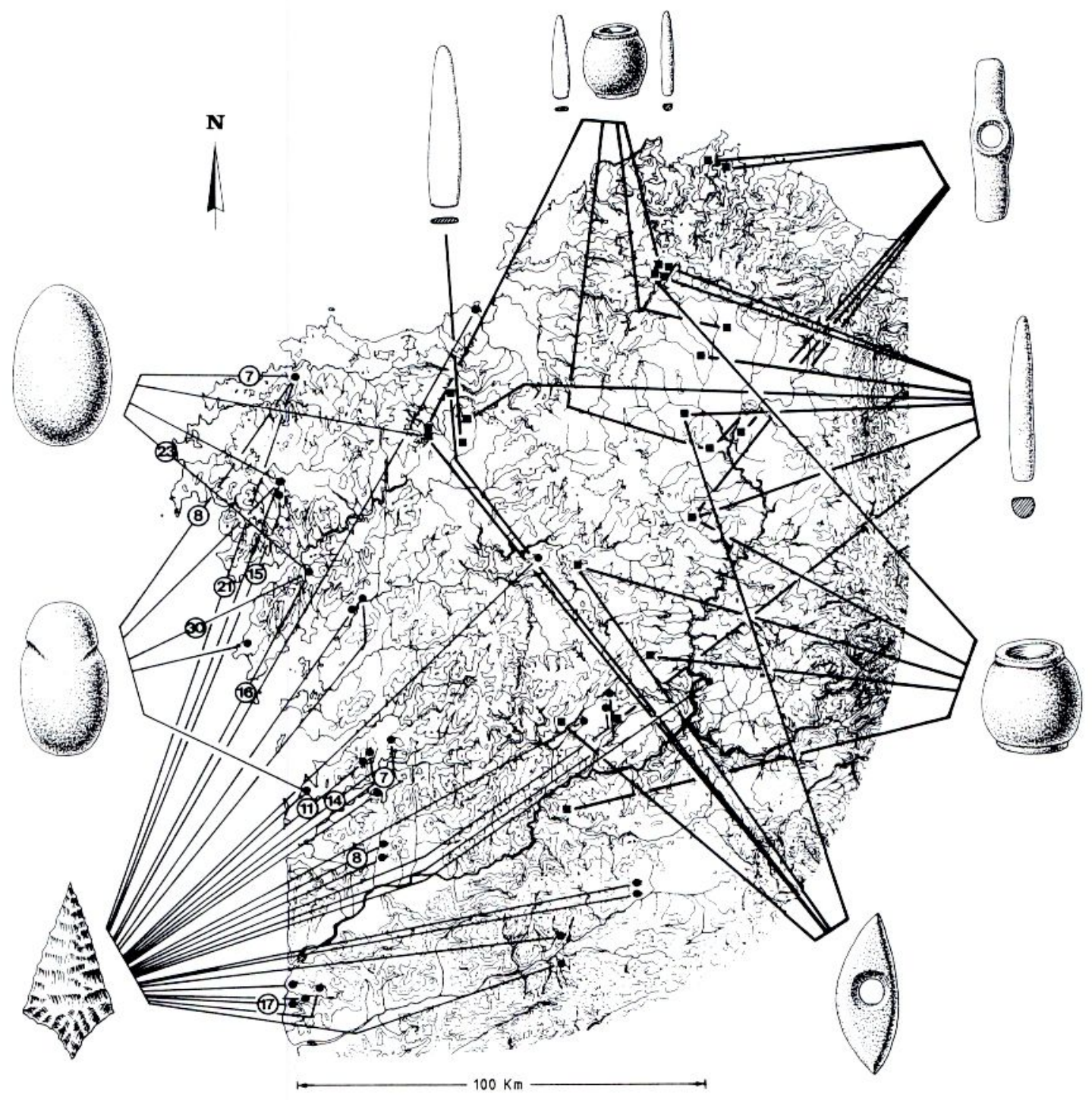

Figure 2

The general distribution of the items considered in Figure 1. The numbers in the circles show the relative frequency of these finds.

with small, low mounds that are assigned a fairly late position in the sequence, in the Beaker period or the earliest Bronze Age (Jorge 1989: 398-399; Criado and Fábregas 1989: 693-694).
Is the distinctiveness of megaliths in the inner plateau confined to the latest period of monument building? Or could they have earlier roots in the same area? Some aspects of the material culture give support to the latter idea.

\section{OXFORD JOURNAL OF ARCHAEOLOGY}


This area contrasts sharply with the coastal region, especially in terms of the number and distribution of arrowheads or other artefacts such as pebble-idols or Argalo-type idols. In both cases these are practically absent in the upper Miño valley and neighbouring districts (Figure 2). The former appear in funerary contexts during the whole of the third millenium and they are particularly common in passage tombs (Fábregas 1990: 124). The latter group are practically restricted to complex passage graves, some of which are very large structures with a distinct forecourt (Criado and Fábregas 1989: 689; Fábregas 1990: 124). Inside these monuments a number of stone idols have been found, some of them set upright in front of the stone walling. They include pebble idols and others decorated with grooves and incisions comprising oblique and converging lines (Figures 1 and 6). In a subtle way these recall the well known facial decoration on a number of Chalcolithic idols from the south and south-west of Iberia (Fábregas A). These comparisons support a context around the middle part of the third millenium BC.

Although there are gaps in our knowledge, this contrast reveals differences between our study area and other parts of north-west Iberia, particularly the Atlantic coastline. The artefact evidence suggests that these contrasts developed at least as early as the first part of the third millenium. They may well be confined to mortuary practice, but they could extend to a wider 'cultural' level (Fábregas 1990). A similar geographical contrast between the upper Miño valley and the coast persists into later periods. It is seen again in the Iron Age Castro Culture (Carballo et al. 1988: 176 and fig. 1).

\section{THE LOCATION OF MONUMENTS}

One of the main lines of enquiry developed during the last decade has been an analysis of the distribution and location of megaliths. Studies of this kind were started in 1979 and, at first, were intended to compensate for a lack of settlement evidence. This approach was typical of the first applications of spatial analysis in archaeology because it focused on the ecological, economic, demographic and social aspects of these sites. Such studies underpinned a series of hypotheses about society and land use in prehistoric communities (Bello et al. 1985 and 1987), but at such an abstract level that the local distribution of the monuments lost its distinctive character. The map of tumuli was simply a means to an end, and these sites no longer retained their importance as a funerary and symbolic phenomenon.

Later, there were attempts to correct this imbalance, emphasizing the ritual and cultural behaviour involved in the location of tumuli. There is an important distinction between two concepts: the term distribution refers to the small scale mapping of tumuli which, in general terms, should reflect the contemporary pattern of settlement. It should shed light on technological, environmental and economic conditions in Galicia. The second term, location, refers to the precise placing of the mounds in the landscape, and this may be more strongly related to ritual and symbolic factors (Criado et al. 1986: 120). At the same time, the analysis of mound location paid particular attention to visibility as one of the fundamental characteristics of tumuli (Criado 1984-85).

However, the location of Galician monuments had still to be studied in detail. There has been considerable progress over the last few years, and intensive surveys have incorporated a systematic analysis of the visibility of megalithic monuments (Vaquero 1989) and their relationship to routes across the landscape (Vaquero 1990). Further work has been initiated, based on the following premise.

The precise location of the tumuli might be

OXFORD JOURNAL OF ARCHAEOLOGY 
regarded as part of their basic design. In other words, the positioning of a monument might form an essential feature of its architecture. On this basis, it was assumed that mound location was not a matter of chance. It was the result of a deliberate choice, based on identifiable criteria (Figure 3 ).

Mobility is the first feature to influence mound location (Infante et al. 1990). This idea suggests that tumuli could be regularly associated with the borders between different components of the landscape. Such a proposal goes further than the traditional observation that megaliths may be associated with ancient roads in Galicia (Bello et al. 1982), France (Germont 1980) or other areas. The pattern is rather more general and relates to a much wider context of movement and social interaction (Vaquero A).

Some of these areas follow specific paths and roads, but there are others only used by wild animals. Recent research (Infante et al. 1990) has helped to define some of these paths by recording the movement of free-ranging animals through the landscape, (in Galicia, communal and uncultivated land has been used, and still is used, as grazing areas for herds of cattle and horses. These animals are gathered once a year but the rest of the time they live and move freely.) This analytical strategy was very successful and showed that these animals maintain a very regular pattern of movement. This is influenced by such features as the location of springs, wet areas, or cooler places that attract the animals in summer. In addition, they are closely related to the traditional pattern of movement among the human population. They follow or cut across land boundaries and incorporate places that play a role in traditional mythology, as well as prehistoric monuments, chapels and Christian crosses. These mark meeting places and are sometimes used for rituals and feasts.

The fact that nearly all the monuments are related to a specific code - even those in what seem to be strange positions (Vaquero 1990) - leads us to believe that the association between monuments and crossing places was very important indeed. This is not so surprising, as such locations enhance the visibility of these sites.

The second locational characteristic links striking natural features with the monuments. The one relationship of this kind is the frequent association between the tumuli and the rock, for some of them are composed of white quartz. One might suppose that this is found because monuments were located close to a source of building stone, but in fact the outcrops attached to monuments were rarely used as quarries. Indeed, these outcrops often consist of a different kind of raw material from the megalithic tombs.

One way of enhancing the pre-eminence and the visibility of a monument is to link it with an important outcrop in the vicinity. This proposal is a little tentative but receives some support from other evidence that certain rocks played a specialized role in megalithic monuments. Outcrops might be incorporated in the structure of the tombs when this was unnecessary in functional terms. Mounds could be covered with a layer of white quartz, or even erected over veins of the rock, emphasizing its distinctive appearance. Quartz could also be employed in intentional deposits within the tumuli themselves.

The third locational factor concerns the connection of the tumuli with settlement areas. The distribution of mounds reveals a radial pattern extending around the areas that would be best suited for settlement and extensive agriculture. There is a clear link between the two zones, as they are normally intervisible.

Although it would be unwise to overemphasize this point, the distribution of the tumuli reflects a wish to link the funerary monuments to the world of the living, for 


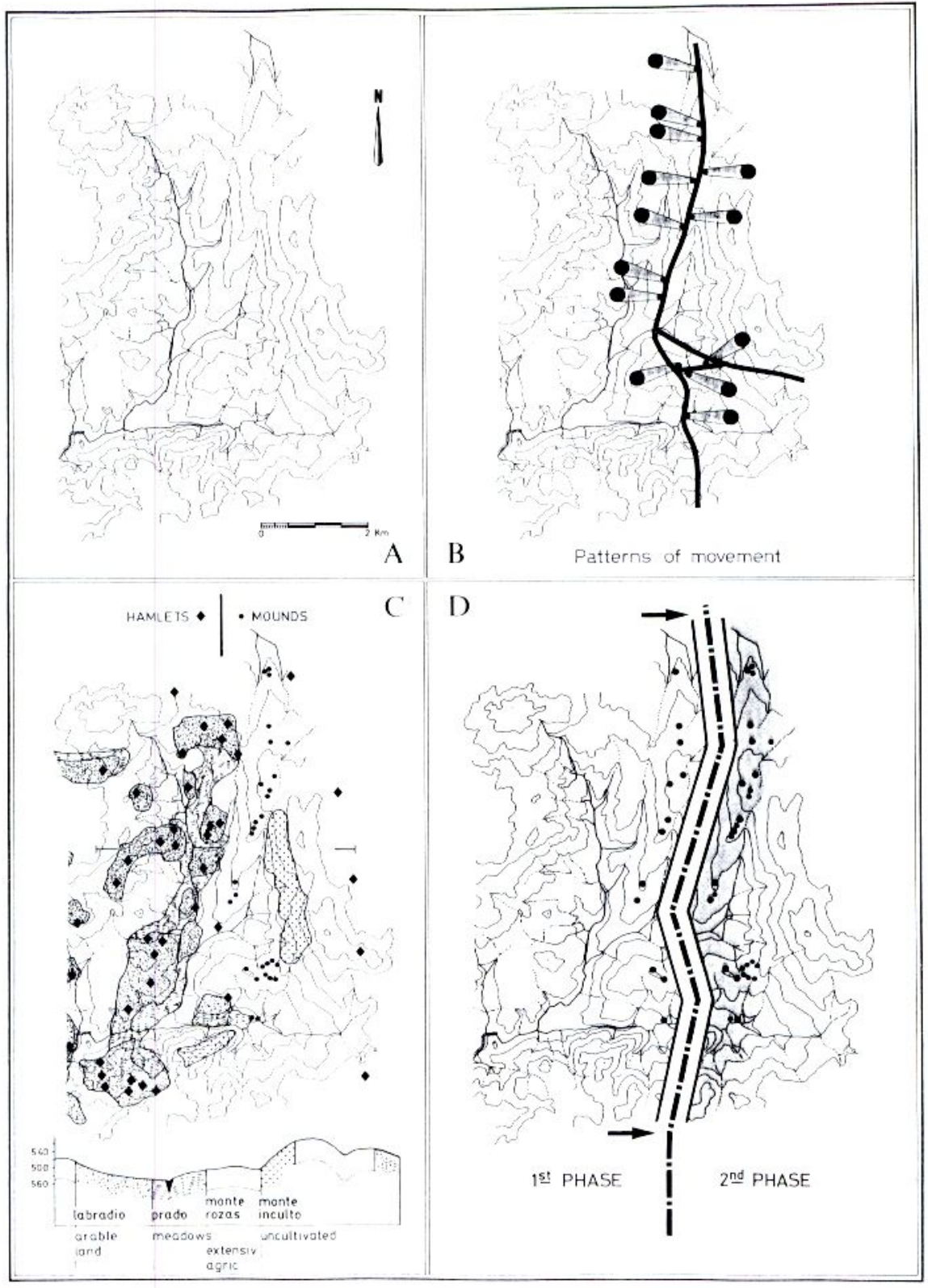

Figure 3

Maps of Cabalar Basin (Coruna) summarising the main factors influencing mound location: (A) the topography of the area; (B) the connection between the mounds and patterns of movement across the territory; (C) the relationship between mounds and traditional land use and settlement; (D) idealized model summarising the effects of time and tradition on mound location: some monuments belonging to the second phase would have been located in relation to existing monuments.

OXFORD JOURNAL OF ARCHAEOLOGY 
occupation sites are occasionally associated with the mounds. Domestic sites have been identified underneath these monuments (Jorge 1984; Cleto and Faro 1988) or within the basins associated with them, the two being intervisible (Criado and Vaquero 1991; González Méndez 1991).

Finally, the fourth locational factor that may have affected Galician megaliths links the monuments with references to cultural order. This feature is important even if it is apparently obvious, for the closest relationship of all is between different monuments. One mound may be associated with another one, or they may occur in much larger numbers. Such juxtapositions sometimes resulted in the development of large cemeteries.

We believe that this process may be related to the creation of tradition (cf. Bradley 1991). By locating a new monument in relationship to an existing mound, its builders linked the two together and offered an image of a tradition. The process also provided a source of legitimacy. The use of a single location for monument building helped to form an effective but imaginary link with previous social happenings.

Limitations of space mean that this account is inevitably rather general and leaves out the local detail on which particular interpretations depend. However, we believe that the location of Galician tumuli was affected by all these factors, singly or in combination. There was obvious scope for local creativity.

\section{THE LOCATION OF MONUMENT CLUSTERS}

Although the location of the mounds has been studied at a detailed level, these factors are probably evident at a larger scale. It may be possible to link these observations with the evidence of regional patterning provided by the grave goods. This may allow us to interpret the large cemeteries or groups of mounds which are such a distinctive feature of the north-west Iberian peninsula.

We have seen how important it is to relate the position of the monuments to the pattern of movement about the local terrain. It is equally important to work in a broader scale. It seems as if the large cemeteries are situated around crossing points between important natural regions with distinctive lithic industries of their own.

Although this observation is rather tentative, there are numerous areas of Galicia in which these factors come together. The clearest instances are provided by the concentrations of mounds bordering the inland area defined in section 2 (Figure 4). Figure 5 illustrates the density of tumuli along the 'Galician divide'. There is an obvious connection between the major crossing points or passes and the concentrations of burial mounds.

These concentrations are very conspicuous. In some cases they are defined by a large number of tumuli (between twenty and forty) clustered over areas of only one or two $\mathrm{km}^{2}$. Even in regions with a high density of mounds, these concentrations rise well above the average. These contain between three and six monuments per $\mathrm{km}^{2}$, compared with a normal figure of one to 1.3. In areas with a higher density of mounds, we can identify clusters of between twelve and fifteen monuments. Such cemeteries are located at a small distance from one another.

These differing types of clustering always correspond with the routes between the inland district and the coastal zone. This relationship is so close, in fact, that the map which defines the communications through the mountainous border to the inner plateau picks out the very same areas as the distribution of some of the most important cemeteries in Galicia (see Figure 4). A more detailed description of these monument complexes is provided in the Appendix.

\section{OXFORD JOURNAL OF ARCHAEOLOGY}




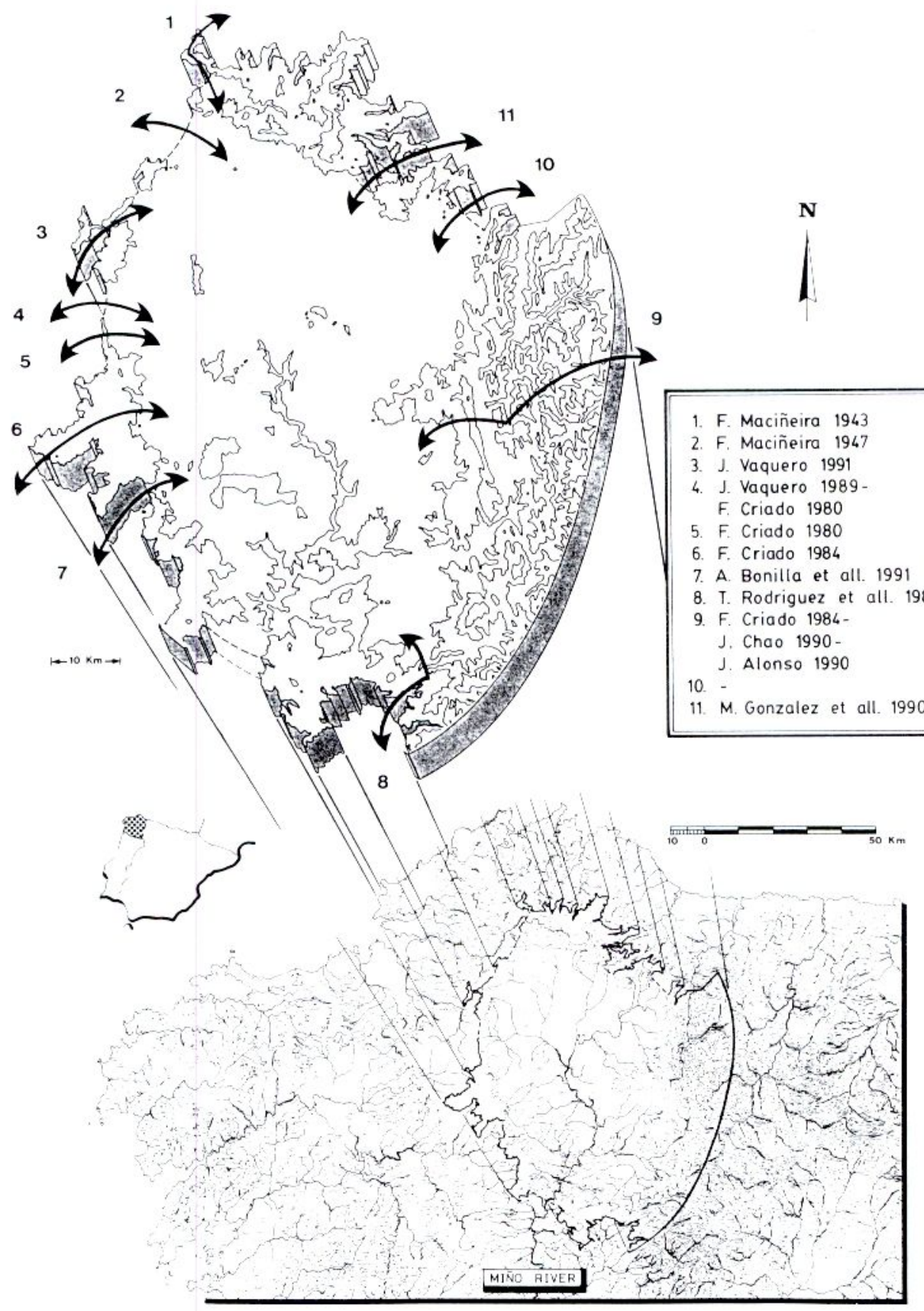

Figure 4

Major routes to the inland area considered in the text (the data are given in the Appendix).

OXFORD JOURNAL OF ARCHAEOLOGY 

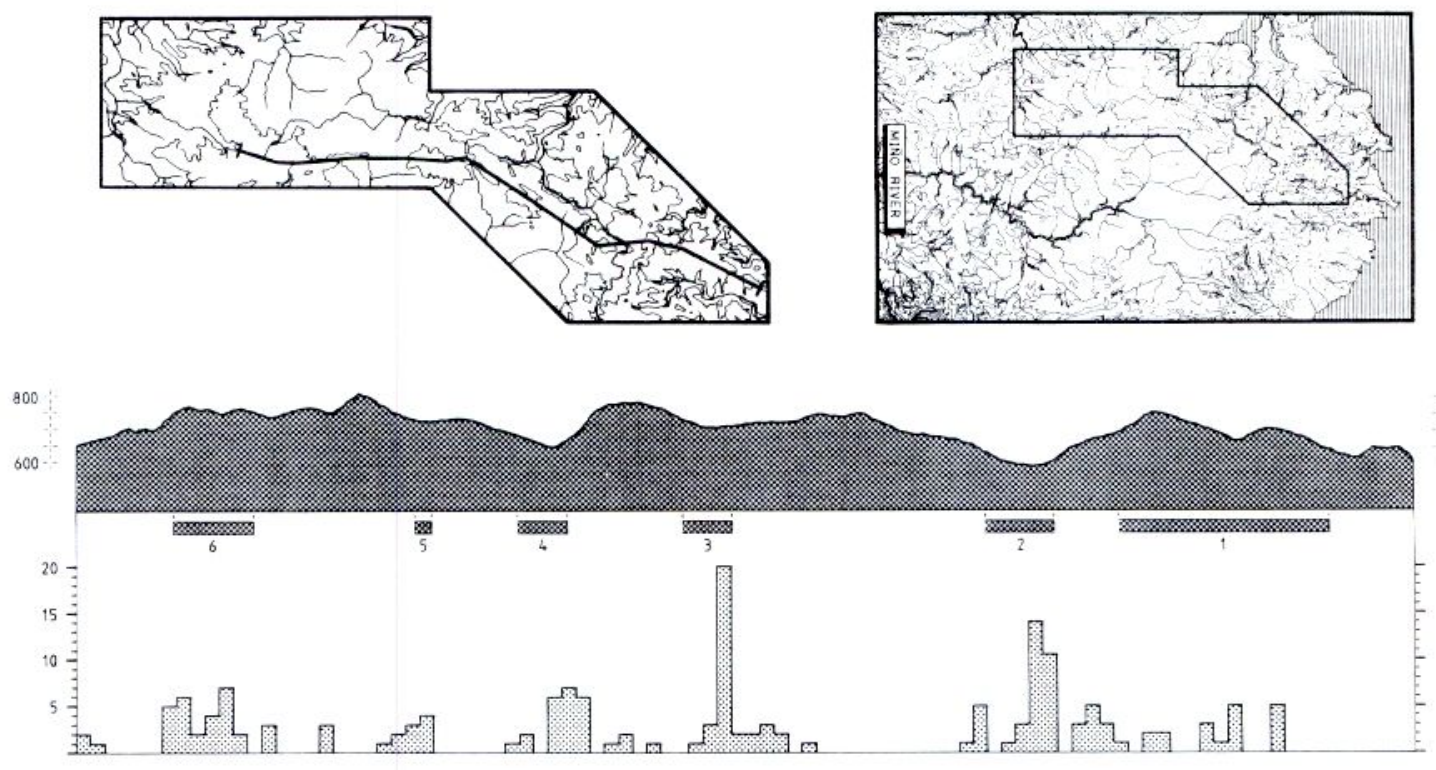

Figure 5

Map of the 'Galician divide' together with a topographical section showing the density of mounds. It is possible to see the close relationship between the number of monuments and the location of the passes through that mountainous barrier.

\section{CONCLUSIONS: TOWARDS AN ARCHAEOLOGY OF MOBILITY}

We can end this study by suggesting a number of conclusions and working hypotheses.

In the first place, it seems clear that the general distribution of tumuli is related to a variety of topographical factors operating at different geographical scales. This has important implications; the position of some individual monuments may be related to the local pattern of movement, whilst the development of enormous cemeteries could be connected to communications across a far more extensive area. We can talk of a 'geography of mobility' at both scales of analysis. This term brings together the topographical setting of megalithic monuments and the importance of those places to prehistoric society (Infante et al. 1990).

\section{OXFORD JOURNAL OF ARCHAEOLOGY}

Basil Blackwell Ltd. 1994
Secondly, it is necessary to integrate such different aspects of the megalithic phenomenon as the study of mound location and stylistic analyses of the grave goods. Taken together, they provide a basis for studying regional patterning within Galicia. In later periods we can identify 'cultural' or 'ethnic' traditions within this region. We have attempted to do the same in relation to the Galician inland plateau.

Lastly, instead of treating these regional traditions as isolated entities, we can investigate the pattern of communication between them. Connections were probably more intense from the middle part of the third millenium $\mathrm{BC}$ and could have followed the same geographical areas as the movement of certain artifacts or raw materials - examples include the flint halberd from San Xoan de Parada, the pottery with symbolic decoration found in Tumulus 5 


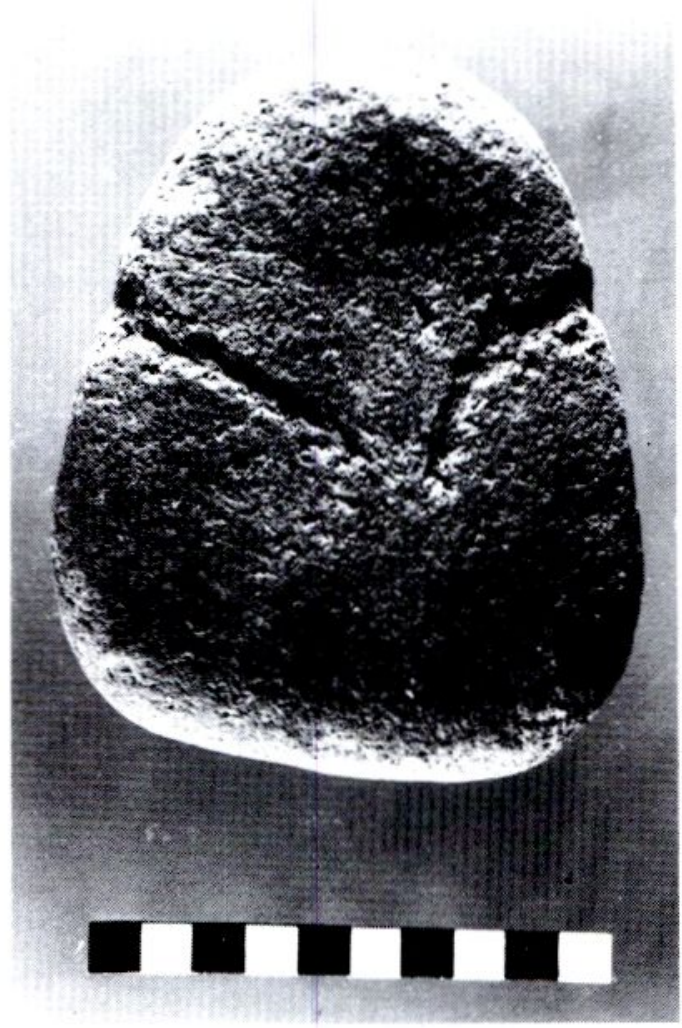

Figure 6

Argalo type idol from Cova da Moura (Noia, La Corunna).

on Monte Pirleo, or the polished stone artifacts mentioned earlier in this paper (Fuente 1988: 102; Fábregas 1991). Such interregional contacts would also explain the importance of the main communication routes across the country and the development of great concentrations of funerary monuments in those areas. This paper is a first attempt to define these phenomena more precisely.

\section{APPENDIX: MOUND CLUSTERS AND NATURAL PASSES IN GALICIA}

Figure 4 picks out the major communication routes,

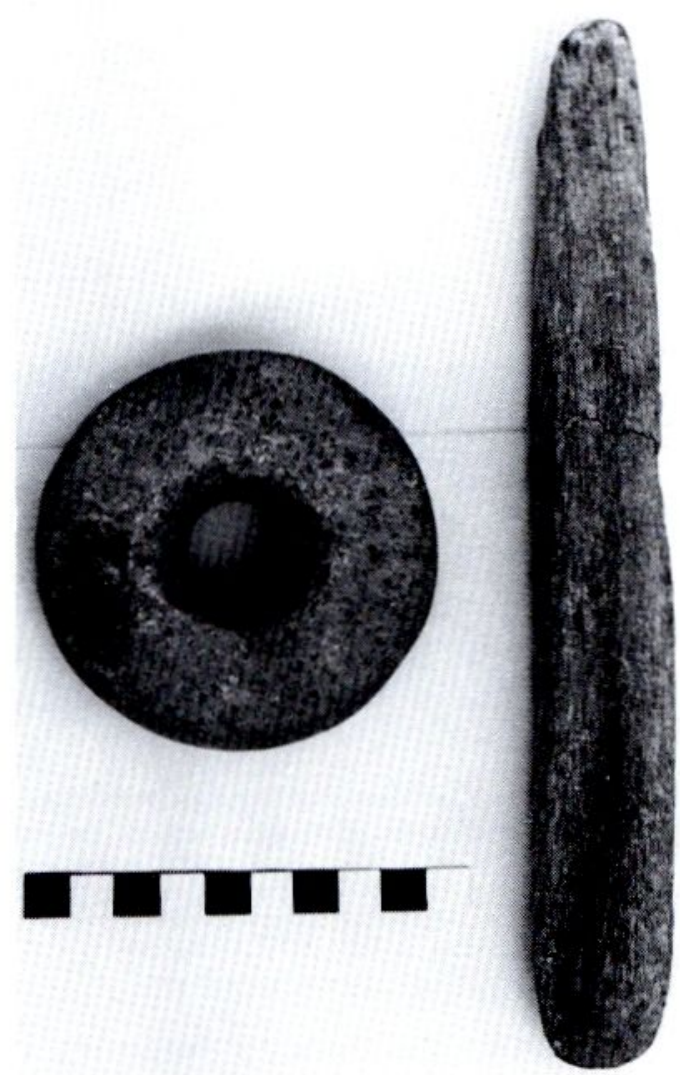

Figure 7

Ground-stone macehead and chisel from Vedro Vello (Castro de Rei, Lugo).

the areas with a high density of monuments and a number of individual cemeteries. The details are as follows.

(1) Camiño Real de Serra Faladoira: a line of 86 tumuli on the edge of a mountain range used to provide access to the inland area from north-west Galicia (Maciñeira 1943 and 1947).

(2) As Pontes de García Rodríquez: there are 104 tumuli, within an area of $37 \mathrm{~km}^{2}$, corresponding with an ancient tertiary basin (Maciñeira 1947).

(3) Cemetery of Galiñeiro: 22 mounds within an area of $2 \mathrm{~km}^{2}$. They are located in a natural pass (Vaquero Lastres forthcoming A).

(4) Teixeiro-Reborica: 122 tumuli in an area of

OXFORD JOURNAL OF ARCHAEOLOGY 


\section{F. CRIADO BOADO AND R. FÁBREGAS VALCARCE}

$46 \mathrm{~km}^{2}$. Most of them belong to small cemeteries of about twelve monuments, which are close together (Vaquero 1991-92 and Criado 1980).

(5) Grixalba (Sobrado): 55 tumuli over an area of $29 \mathrm{~km}^{2}$, most of them isolated or in groups of three or four (Criado 1980).

(6) A Serra do Bocelo (Coruña): 35 monuments over an area of $20 \mathrm{~km}^{2}$ (Criado Boado 1980 and Criado \& Vaquero 1991).

(7) At present there is not enough information to substantiate our hypothesis. Intensive survey work is now in progress.

(8) Cemetery at Santa Mariña: nearly forty mounds on the mountain range that divides the districts of Incio and Sarria (Lugo). (We are grateful to Tomás Fernández, Ana Filgueiras and their team for this information.)

(9) A Fonsagrada (Lugo): recent surveys in the eastern mountains of Galicia have revealed huge concentrations of mounds, some of them distributed in lines beside roads along the higher ground. In other cases they appear in small clusters, (field-work by F. Criado in 1984, supplemented by more recent surveys undertaken by Alonso Braña and Javier Chao Rego).

Areas 10 and 11 represent other important communication routes, where tumuli have not been recorded. Area 11 has been intensely surveyed by $\mathrm{M}$. González and F. Méndez, to whom we owe this information. The north of Galicia does not seem to have played an important part in the distribution of megaliths, and constructions of this type are rarely discovered. Area 10 has still to be studied in the field. The finding of a significant concentration of tumuli at that point would support the hypothesis proposed in this paper.

(1) Departamento de Historia I, Area de Prehistoria, Universidade de Santiago de Compostela. 15703 Santiago (Spain).

(2) Departamento de Historia, Area de Prehistoria, Universidade de Vigo. 32004 Ourense (Spain).

\section{REFERENCES}

BELLO DIEGUEZ, J.M., CRIADO BOADO. F. AND VAZQUEZ VARELA, J.M., 1982: Sobre la cultura megalítica y los caminos antiguos en Galicia. Museo de Pontevedra, 36 , $143-64$.

BELLO DIEGUEZ, J.M., CRIADO BOADO, F. AND VAZQUEZ VARELA, J.M., 1987: La cultura megalítica de la provincia de la Coruña y sus relaciones con el marco natural: implicaciones socio-económicas. (Diputación Provincial, Coruña.)

BELLO DIEGUEZ, J.M., CRIADO BOADO, F. AND VAZQUEZ VARELA, J.M. 1985: Cultura megalítica y medio natural en el NW peninsular. Coloquio sobre distribución y relaciones entre los asentamientos. (Teruel, 1984), Arqueologia Espacial, 6, 229-35. (Teruel.)

BOCQLeT, A. AND Holot, A., 1982: La vie au Néolithique. Charavines, un village au bord d'un lac il y a 5000 ans. Histoire et Archeologie, 64, (Dijon.)

BRADLEY, R., 1991: Ritual, time and history. World Archaeology, 23: 2, 209-19.

CLETO, J.A. AND FARO, S., 1988: Escavaçâo da mamoa de Igrejinhas, Arqueologia, 17, 44-57.

CRIADO BOADO, F, 1984-5: 'El tercer factor' o la lógica oculta del emplazamiento de los túmulos megalíticos gallegos. Cuadernos de Estudios Gallegos, 35: 100 . $7-18$.

CRIADO BOADO, F., 1980: Catalogación de mámoas en los municipios de Curtis, Sobrado y tierras adyacentes. Brigantium, 1, 13-40.

CRIADO BOADO, F., 1988: Arqueología del Paisaje y Paisaje Megalitico en Galicia. Arqueología Espacial, 12, $61-117$.

CRIADO BOADO. F. 1989: Contribución al estudio de las relaciones entre las comunidades megalíticas del Noroeste peninsular y su medio natural: implicaciones socioeconómicas. (PhD Dissertation read at the University of Santiago de Compostela.)

CRIADO BOADO, F., 1989a: Megalitos, espacio, pensamiento. Trabajos de Prehistoria, 46, 75-98

CRIADO BOADO, F., 1989b: Asentamiento Megalítico y Asentamiento Castreño: una propuesta de síntesis. Gallaecia, 11, 109-37.

CRIADO BOADO, F., 1989c: 'We, the post-megalithic people ... ', In I. Hodder (ed.) The Meaning of Things. Material Culture and Symbolic Expression, 79-89. (London: Unwin Hyman.)

\section{OXFORD JOURNAL OF ARCHAEOLOGY}


CRIADO BOADO, F., AIRA RODRIGUEZ M J. AND DIAZ-FIERROS VIQUEIRA, F., 1986: La construccion del paisaje. Megalitismo y Ecología en la Sierra de Barbanza. Galicia, Dirección Xeral do Patrimonio Artístico e Monumental.)

CRIADO BOADO. F. AND FABREGAS VALCARCE, R., 1989 The megalithic phenomenon of NW Spain: main trends

CRIADO BOADO, F. AND VAQUERO LASTRES, J.A. 1991 Formas diversas de pasado monumental. In F. Criado et al. La Arqueología del Paisaje en Galicia. El área Bocelo-Furelos desde el Paleolítico Superior Final hasta la Epoca Medieval. (Campañas de 1987, 1988 y 1989). Arqueoloxía-Investigación, 6. (Santiago.)

CRIADO BOADO, F, AND VAQUERO L.ASTRES, J.A., 1993 Monumentos, nudos en el pañuelo, megalitos, nudos en el espacio. Análisis del emplazamiento de los monumentos tumulares gallegos. Espacio, Tiempo y Forma-Prehistoria-, 6 (forthcoming).

DELIBRIAS, G. AND LE ROUX. C.-T. 1975: Un exemple d'application des datations radiocarbone à l'interpretation d'une stratigraphie complexe: la fouille des ateliers de Plussulien (Côtes-du-Nord), Bulletin de la Société Préhistorique Française, 72, 78-82.

FABREGAS VALCARCE, R., 1988: Cronología y periodización del megalitismo en Galicia y Norte de Portugal. Espacio, Tiempo y Forma-Prehistoria-, 1, 279-291.

FABREgas VAlCARCE, R., 1988a: Megalitismo de Galicia. Coloquio de Arqueología do NW Peninsular, (PortoBaiâo, 1988). Trabalhos de Antropologia e Etnologia, 28, 57-73. Porto

FABREGAS VALCARCE, R. 1988b: La industria lítica pulimentada. Aproximaciones a la cultura material del megalitismo gallego (R. Fábregas and F. de la Fuente), Arqueohistórica, 2, 15-53. (Santiago de Compostela.)

FABREGAS VALCARCE, R., 1989; Le phénomène du mégalithisme dans le Nord-Ouest de I'Espagne. L'Anthropologie. 93-1, 219-230.

FABREGAS VALCARCE, R., 1990: Industria litica en el megalitismo del Noroeste peninsular: consideraciones $105-141$.

FABREGAS VALCARCE, R., 1991: Megalitismo del Noroeste. Tipologia y secuencia de los materiales liticos. Aula Abierta, 58 (Madrid.) Arqueoloxía-Investigación, 2. (Santiago: Xunta de Antiquity, 63, 682-696 generales. Espacio, Tiempo y Forma-Prehistoria-, 3 ,

FABREgas VALCARCE, R., A: Stone figures in PassageGraves of Galicia (NW Spain). Paper read at the XIIth U.I.S.P.P. Congress, (Bratislava (Slovakia), 1-7 September 1991.)

FUENTE ANDRES, F. de la, 1988: El material cerámico. Aproximaciones a la cultura material del megalitismo gallego (R. Fábregas Valcarce and F. de la Fuente Andrés), (Santiago), 73-154.

GACHINA, J., GOMEZ, J. and COFFIN, A., 1975: Supplément à l'inventaire des instruments perforés pour les départements de Charente, Charente-Maritime et Gironde. Bulletin de la Société Préhistorique Française. 72. $368-381$

GERMONT, N., 1980: Inventaire des megalithes de la France: 6, Deux-Sevres. $6^{\circ}$ Supplement á Gallia Prehistoire (Paris).

GONZALEZ MENDEZ, M., 1991: Yacimientos del III Milenio A.C.: entre la problemática del calcolítico y un pasado huidizo. In F. Criado et al. La Arqueología del Paisaje en Galicia. El área Bocelo-Furelos desde el Paleolítico Superior Final hasta la Epoca Medieval. (Campañas de 1987, 1988 y 1989). ArqueoloxíaInvestigación, 6. (Santiago.)

INFANTE ROURA F., VAQUERO LASTRES, J. and CRIADO BOADO, F., 1990: Vacas, caballos, abrigos y túmulos: definición del movimiento para el estudio arqueológico. Cuadernos de Estudos Galegos, 105, 21-39.

JORGE, V.O., 1984: Escavaçâo da mamoa da Mina do Simâo, Arqueologia, 9, 3-21.

JORGE, V.o., 1988: Campo arqueológico da Serra da Aboboreira. Arqueologia do concelho de Baiâo. Resultados de 10 anos de trabalho. Arqueologia, 17, $5-27$.

JORGE, V.O., 1989: Arqueologia social dos sepulcros megalíticos atlânticos: conhecimentos e perspectivas actuais. Revista da Faculdade de Letras, 6, 365-443.

LE ROUX. C.T., 1979: Stone axes of Brittany and the Marches. Stone Axe Studies eds. T.H. McK. Clough and W.A. Cummins. (C.B.A. Research Report, 23), 49-56.

LOPEZ CleVILLAS, F., 1959: La época megalítica en el Noroeste de la Península. Caesaraugusta, 13-14, $21-77$

MACIÑEIRA Y PARDO DE LAMA, F., 1943: Túmulos prehistóricos. Inventario descriptivo de los doscientos ochenta y seis túmulos prehistóricos hasta ahora descubiertos en la avanzada comarca del Cabo Ortegal.

OXFORD JOURNAL OF ARCHAEOLOGY 
Boletin de la Real Academia Gallega, 33, 21-29. $124-35,178-86,236-39$ and $314-21$.

MaciñeIra y PARdo de Lama, F., 1947: Bares. Puerto hispánico de la primitiva navegación occidental. (Madrid.)

NONN, H., 1966: Les régions côtières de la Galice (Espagne). (Paris.)

Perez alberti, A., 1986: Galicia. A xeografía, o espacio xeográfico e o home. (Vigo.)

RODRIGUEZ CASAL. A.-A., 1990: Die Megalithkultur in Galicien. Probleme der Megalithgräberforschung, (Berlin), 53-72.

ROE. F.E.S. 1979: Typology of stone implements with shaftholes. Stone Axe Studies eds. T.H. McK. Clough and W.A. Cummins, (C.B.A. Research Report, 23) $23-48$.

SMITH. 1.F., 1979: The chronology of British stone imple- ments. Stone Axe Studies (eds. T.H. McK. Clough and W.A. Cummins, (C.B.A. Research Report, 23) $13-22$.

VAQUERO LASTRES, J., 1989: ¿Donde diablos se esconden nuestros muertos que no los podemos ver?. Reflexiones sobre el emplazamiento de los túmulos del NW. Gallaecia, 11, 81-108.

VAqUeRO LASTRES. J. 1990: Rios y tumbas. Reflexiones sobre el emplazamiento de los túmulos del NW. Trabalhos de Anthropologia e Etnologia, 29, 151-168.

VAQUero LASTRES, J.. 1991-1992: Del análisis del emplazamiento al estudio de la distribución de túmulos en el NW. Brigantium, 7, 151-176.

VAquero Lastres, J.. A: Galiñeiro, paso de novios, lobos y héroes. Reflexiones sobre el emplazamiento tumular del NW. Guadernos de Estudos Galegos (forthcoming).

\section{OXFORD JOURNAL OF ARCHAEOLOGY}

